\title{
PERBEDAAN KEMAMPUAN KONEKSI MATEMATIK SISWA MELALUI PEMBELAJARAN KONTEKSTUAL DENGAN KOOPERATIF TIPE STAD DI SMP NEGERI 1 SILOU KAHEAN
}

\author{
Asmy Susilawaty Saragih ${ }^{1}$, Sahat Saragih ${ }^{2}$ \\ ${ }^{1 .}$ Mahasiswa FMIPA, Universitas Negeri Medan \\ ${ }^{2 .}$ Dosen FMIPA, Universitas Negeri Medan
}

\begin{abstract}
Abstrak
Penelitian ini bertujuan untuk mengetahui gambaran (1) Kemampuan koneksi matematik siswa yang mengikuti pembelajaran matematika dengan model pembelajaran Kontekstual lebih tinggi daripada siswa yang mengikuti model pembelajaran Kooperatif Tipe STAD, serta (2) Proses jawaban siswa terkait kemampuan koneksi matematik yang diajarkan melalui Pembelajaran Kontekstual dan Kooperatif Tipe STAD. Penelitian ini merupakan penelitian quasi experimental dengan populasi seluruh siswa kelas VII SMPN 1 Silou Kahean sebanyak 5 kelas. Sampel diambil melalui teknik cluster random sampling, diperoleh kelas VII-3 sebagai kelompok eksperimen I yang diajar dengan model pembelajaran kontekstual dan kelas VII-4 sebagai kelompok eksperimen II yang diajar dengan model pembelajaran kooperatif tipe STAD. Pengumpulan data dilakukan dengan metode tes dan metode observasi. Metode tes dilakukan untuk memperoleh data nilai akhir setelah diberi perlakuan pada kelompok eksperimen I dan kelompok eksperimen II. Sebelum instrumen diberikan pada siswa terlebih dahulu diujicoba dengan perhitungan validitas dan reliabilitas. Data dianalisis dengan uji normalitas, uji kesamaan dua varians, dan uji hipotesis menggunakan uji-t.

Berdasarkan hasil perhitungan data postes siswa diperoleh pada dk 66 dan $\alpha=0,05$ diperoleh $t_{\text {tabel }}=1,669$ dan $t_{\text {hitung }}=2,398$. Karena $t_{\text {hitung }}>t_{\text {tabel }}(2,398>1,669)$ maka Ho ditolak dan $\mathrm{H}_{1}$ diterima. Maka dapat disimpulkan bahwa kemampuan koneksi matematik siswa yang diajar dengan model pembelajaran kontekstual lebih tinggi daripada siswa yang diajar dengan model pembelajaran kooperatif tipe STAD. Berdasarkan hasil penelitian ini, model pembelajaran kontekstual (CTL) dapat dijadikan sebagai alternatif model pembelajaran untuk meningkatkan kemampuan koneksi matematik siswa khususnya pada materi bangun datar segiempat.
\end{abstract}

Kata Kunci : Kemampuan Koneksi Matematik, CTL, Kooperatif Tipe STAD.

\begin{abstract}
This study aims to describe (1) The ability of mathematical connections of students who take mathematics learning with contextual learning model is higher than the students who take the STAD type of cooperative learning model, and (2) the student answers related to process mathematical connection capability is taught through contextual learning and STAD type of cooperative. This research is a quasi experimental with the entire population of the seventh grade students of SMPN 1 Silou Kahean TA 2014/2015 as much as 5 classes. Samples were taken through a random cluster sampling technique, derived class VII-3 as the first experimental group were taught using contextual learning model and class VII-4 as an experimental group II, taught by cooperative learning model type STAD. Data collection is
\end{abstract}

Asmy Susilawaty Saragih, Sahat Saragih Perbedaan Kemampuan Koneksi Matematik Siswa Melalui Pembelajaran Kontekstual dengan Kooperatif Tipe STAD di SMP Negeri 1 Silou Kahean. Jurnal Inspiratif, Vol. 4 No. 1 April 2018 
done with test method and observation method. Method tests conducted to obtain data on the final value after being treated in the experimental group I and group II experiments. Before the instrument is given to students prior to the calculation tested the validity and reliability. Data were analyzed with normality test, the equality of two variances, and hypothesis testing using $t$ test. Based on the results of the calculation of the data obtained in the posttest students dk 66 and $\alpha=0.05$ was obtained $T_{-}($table $)=1.669$ and $T_{-}($count $)=2.398$. Because $T_{-}$(count $)>T_{-}$ (table) (2.398> 1.669), then Ho is rejected and accepted $H_{-} 1$. It can be concluded that the ability of students taught mathematical connection with contextual learning model is higher than students taught by cooperative learning model type STAD. Based on these results, contextual learning model (CTL) can be used as an alternative model of learning to improve student math connections, especially on waking material flat rectangle. Keywords: Connection Capability Mathematics, CTL, STAD Cooperative mode

\section{PENDAHULUAN}

Pendidikan memegang peranan penting dalam proses peningkatan kualitas sumber daya manusia (SDM). Pendidikan diyakini akan dapat mendorong memaksimalkan potensi siswa sebagai calon SDM yang handal untuk masa yang akan datang yang harus dapat bersikap kritis, logis dan inovatif dalam menghadapi dan menyelesaikan setiap permasalahan yang dihadapinya. Oleh karena itu, peningkatan kualitas sumber daya manusia merupakan kenyataan yang harus dilakukan secara terencana, terarah, intensif, efektif, dan efisien dalam proses pembangunan, kalau tidak ingin bangsa kalah bersaing dalam menjalani era globalisasi tersebut.

$$
\text { Pendidikan memberikan }
$$

kemungkinan pada siswa untuk memperoleh "kesempatan", "harapan", dan pengetahuan agar dapat hidup secara lebih baik. Besarnya kesempatan dan harapan sangat bergantung pada kualitas pendidikan yang ditempuh. Pendidikan juga dapat menjadi kekuatan untuk melakukan perubahan agar sebuah kondisi menjadi lebih baik. Pendidikan yang berkualitas tentunya melibatkan siswa untuk aktif belajar dan mengarahkan terbentuknya nilai-nilai yang dibutuhkan oleh siswa dalam menempuh kehidupan (Surya, Putri dan Mukhtar, 2017)

Pendidikan merupakan keseluruhan proses dimana seseorang mengembangkan kemampuan, sikap dan bentuk - bentuk tingkah laku lainnya yang bernilai positif dalam masyarakat di tempat hidupnya. Salah satu jalur pendidikan yang sangat akrab di lingkungan kita adalah pendidikan formal yang pelaksanaannya diatur oleh pemerintah. Pendidikan formal pada intinya adalah kegiatan belajar mengajar dimana komponen yang terlibat dalam proses belajar ini meliputi: guru, siswa, kurikulum dan sarana penunjang pendidikan. Salah satu mata pelajaran yang diberikan disetiap jenjang pendidikan yang dapat meningkatkan kualitas SDM adalah matematika. Hal ini sesuai dengan pendapat Cockfort (dalam Abdurrahman, 2012:204) mengemukakan bahwa: "Matematika perlu diajarkan kepada siswa karena (1) selalu digunakan dalam segala segi kehidupan; (2) semua bidang studi memerlukan keterampilan matematika yang sesuai; (3) merupakan sarana komunikasi yang kuat, singkat, dan jelas; (4) dapat digunakan untuk menyajikan informasi dalam berbagai cara; (5) meningkatkan kemampuan berpikir logis, ketelitian, dan kesadaran keruangan; dan (6) memberikan kepuasan terhadap usaha memecahkan masalah yang menantang".

Asmy Susilawaty Saragih, Sahat Saragih $\quad$ Perbedaan Kemampuan Koneksi Matematik $\quad$ Siswa Melalui Pembelajaran Kontekstual dengan Kooperatif Tipe STAD di SMP Negeri 1 Silou Kahean. Jurnal Inspiratif, Vol. 4 No. 1 April 2018 
Sebagai salah satu bidang studi yang diajarkan pada setiap jenjang pendidikan, matematika menuntut siswa kepada pola pikir untuk memecahkan masalah. Hal ini sesuai dengan tujuan diajarkannya mata pelajaran matematika di SD, SMP, SMA dan SMK (http://p4tkmatematika.org, 2011) yaitu:

1. Agar peserta didik memiliki kemampuan memahami konsep matematika, menjelaskan keterkaitan antar konsep dan mengaplikasikan konsep atau algoritma, secara luwes, akurat, efisien, dan tepat dalam pemecahan masalah.

2. Menggunakan penalaran pada pola dan sifat, melakukan manipulasi matematika dalam membuat generalisasi, menyusun bukti, atau menjelaskan gagasan dan pernyataan matematika.

3. Memecahkan masalah yang meliputi kemampuan memahami masalah, merancang model matematika, menyelesaikan model dan menafsirkan solusi yang diperoleh.

4. Mengkomunikasikan gagasan dengan simbol, tabel, diagram, atau media lain untuk memperjelas keadaan atau masalah.

5. Memiliki sikap menghargai kegunaan matematika dalam kehidupan yaitu memiliki rasa ingin tahu, perhatian, dan minat dalam mempelajari matematika, serta sikap ulet dan percaya diri dalam pemecahan masalah.

Matematika tidak hanya menuntut siswa mampu memecahkan masalah matematika tetapi juga masalah pada kehidupan sehari - hari. Seperti yang dikemukakan oleh Cornelius (dalam Abdurrrahman, 2012: 204) mengemukakan alasan perlunya siswa belajar matematika: "Lima alasan perlunya siswa belajar matematika karena matematika merupakan
(1) sarana berpikir yang jelas dan logis; (2) sarana untuk memecahkan masalah kehidupan sehari - hari; (3) sarana mengenal pola - pola hubungan dan generalisasi pengalaman; (4) sarana untuk mengembangkan kreativitas; (5) sarana untuk meningkatkan kesadaran terhadap perkembangan budaya".

Sekalipun demikian, mata pelajaran matematika belum menjadi mata pelajaran yang diminati oleh banyak siswa. Siswa masih beranggapan matematika itu sulit. Hal ini disebabkan oleh pandangan mereka bahwa matematika merupakan seperangkat fakta - fakta atau rumus - rumus yang harus dihadapi. Selain itu objek matematika yang abstrak, konsep dan prinsipnya berjenjang, dan prosedur pengerjaannya yang banyak memanipulasi bentuk - bentuk dan menghubungkan ide - ide matematika ternyata menimbulkan anggapan siswa bahwa matematika itu sulit.

Hal tersebut mengakibatkan kemampuan berpikir matematis siswa rendah diantaranya adalah kemampuan pemecahan masalah matematik, komunikasi matematik, penalaran dan pembuktian matematik, koneksi matematik dan representase matematik. Dari kelima kemampuan berpikir matematis tersebut, dengan tidak mengabaikan kemampuan yang lain, kemampuan koneksi matematik merupakan bagian penting dalam aktivitas dan penggunaan matematika yang dipelajari siswa. Pentingnya kemampuan ini dijelaskan dalam standar kompetensi bahan kajian matematika kurikulum yang berlaku saat ini pada tingkat Sekolah Menengah Pertama (SMP). Dalam standar ini dijelaskan bahwa siswa dituntut untuk memiliki kemampuan mengkomunikasikan gagasan dengan simbol, skema, tabel, grafik atau diagram untuk memperjelas suatu keadaan atau masalah, menunjukkan kemampuan dalam membuat, menafsirkan,

Asmy Susilawaty Saragih, Sahat Saragih $\quad$ Perbedaan Kemampuan Koneksi Matematik Siswa Melalui Pembelajaran Kontekstual dengan Kooperatif Tipe STAD di SMP Negeri 1 Silou Kahean. Jurnal Inspiratif, Vol. 4 No. 1 April 2018 
dan menyelesaikan model matematika dalam pemecahan masalah, dan memiliki sikap menghargai kegunaan matematika dalam kehidupan sehari - hari.

Koneksi matematik merupakan bagian yang sangat penting dalam pembelajaran matematika. Hal ini dikarenakan dalam dunia pendidikan, kemampuan menghubungkan suatu materi yang satu dengan materi yang lain atau dengan kehidupan sehari - hari berperan penting dalam proses pembelajaran terutama dalam pembelajaran matematika. Koneksi matematik adalah keterkaitan antara topik matematika, keterkaitan antara matematika dengan disiplin ilmu lain, dan keterkaitan matematika dengan dunia nyata atau kehidupan sehari - hari. Melalui kemampuan koneksi matematik, kemampuan berfikir kritis siswa terhadap matematika diharapkan dapat menjadi semakin luas. Selain itu, koneksi matematik dapat pula meningkatkan kemampuan kognitif siswa seperti mengingat kembali, memahami penerapan suatu konsep terhadap lingkungan dan sebagainya.

Begitu penting kemampuan koneksi matematik siswa dalam proses pembelajaran, namun kenyataannya kemampuan koneksi matematik siswa masih rendah. Terutama dalam menyelesaikan masalah yang berhubungan dengan kehidupan sehari - hari atau soal cerita. Siswa masih kurang bisa menentukan data - data apa saja yang dapat diperoleh dari soal cerita itu, bagaimana menghubungkannya dengan materi matematika dan melihat keterkaitannya dengan materi yang lain. Hal ini berarti siswa kurang mampu memahami keterkaitan antar materi sehingga kemampuan koneksi matematik siswa rendah. Hal ini sesuai dengan pendapat Ruspiani (2000) yang menyatakan bahwa kemampuan koneksi matematik siswa masih tergolong rendah, nilai rata - ratanya kurang dari 60 pada skor 100, yaitu sekitar 22,2 \% untuk koneksi matematika dengan pokok bahasan lain, 44,9\% untuk koneksi matematika dengan bidang studi lain, dan $67,3 \%$ untuk koneksi matematik dengan kehidupan keseharian.

Sejalan dengan itu, dari hasil observasi di kelas yang dilaksanakan pada tanggal 15 Januari 2015, penulis menemukan siswa kesulitan dalam menyelesaikan soal yang membutuhkan koneksi, baik koneksi antar topik matematika, koneksi matematika dengan disiplin ilmu lain maupun dengan kehidupan sehari - hari. Sebagai contoh kasus, dalam sebuah kapal laut terdapat 300 orang penumpang. Jumlah penumpang pria adalah 175 orang. Berapakah persentase penumpang pria dan persentase penumpang wanita? Untuk menyelesaikan soal tersebut siswa harus mampu menuliskan permasalahan tersebut dalam konsep bilangan pecahan dimana siswa harus mengetahui mana pembilang dan mana penyebut dalam soal tersebut, serta dimana untuk menyelesaikannya membutuhkan koneksi antar topik matematika.

Siswa kesulitan menjawab soal tersebut dengan benar, siswa mengalami kesulitan dalam menerjemahkan soal tersebut ke dalam bentuk matematis. Umumnya siswa tidak bisa mengubah pecahan biasa ke pecahan campuran dan dari pecahan campuran ke bentuk desimal. Dari 36 orang siswa, 12 orang siswa hanya bisa menuliskan, misalkan $\frac{175}{300} \times 100$, namun tidak bisa menyelesaikannya dan sisanya tidak menjawab atau jawabannya salah.

Surya dan Syahputra (2017) mengemukakan bahwa kegagalan dalam matematika sekolah sebagian besar terkait dengan tradisi pengajaran yang tidak sesuai dengan cara kebanyakan siswa belajar. Metode pengajaran matematika tradisional

Asmy Susilawaty Saragih, Sahat Saragih Perbedaan Kemampuan Koneksi Matematik Siswa Melalui Pembelajaran Kontekstual dengan Kooperatif Tipe STAD di SMP Negeri 1 Silou Kahean. Jurnal Inspiratif, Vol. 4 No. 1 April 2018 
telah ditemukan sangat cacat dan penuh dengan banyak kekurangan yang tidak memungkinkan siswa untuk secara aktif membangun pengetahuan matematika mereka sendiri.

Rendahnya kemampuan koneksi matematik siswa ini bisa terjadi karena model pembelajaran yang digunakan guru bidang studi matematika kurang melatih keterampilan atau kemampuan koneksi matematik siswa. Berdasarkan hasil wawancara dengan Bapak Saragih salah satu guru matematika SMP Negeri 1 Silou Kahean, ditemukan bahwa sebagian besar guru termasuk Bapak Saragih masih menggunakan pembelajaran konvensional dimana pembelajaran masih berpusat pada guru, karena metode ceramah lebih mudah digunakan dalam pembelajaran. Selain itu ditemukan juga bahwa aktivitas belajar siswa masih rendah dan siswa di kelas tersebut masih mengalami kesulitan dalam menyelesaikan soal koneksi karena pembelajaran yang berlangsung selama ini mengabaikan aspek keterkaitan matematika dengan topik matematika sebelumnya, dengan disiplin ilmu lain dan dengan masalah - masalah nyata di sekitar kehidupan sehari - hari siswa. Hal ini sejalan dengan pendapat Kurniati (2010:5) yang menyatakan bahwa pembelajaran matematika di kelas masih cenderung menggunakan paradigma lama dengan menyajikan pengetahuan matematika tanpa mengaitkannya dengan kehidupan sehari hari.

Selama ini model pembelajaran yang digunakan guru adalah model pembelajaran konvensional. Pada pembelajaran ini suasana kelas cenderung teacher oriented sehingga siswa menjadi pasif, jenuh dan bosan yang menyebabkan pencapaian hasil belajar tidak optimal. Trianto (2011:5) mengemukakan bahwa:

"Masalah utama dalam pembelajaran pada pendidikan formal (sekolah) dewasa ini adalah masih rendahnya daya serap peserta didik. Hal ini dari rerata hasil belajar peserta didik yang senantiasa masih sangat memprihatinkan. Prestasi ini tentunya merupakan hasil kondisi pembelajaran yang masih bersifat konvensional dan tidka menyentuh ranah dimensi peserta didik itu sendiri, yaitu bagaimana seharusnya belajar itu (belajar untuk belajar). Dalam arti yang lebih substansial, bahwa proses pembelajaran hingga dewasa ini masih memberikan dominasi guru dan tidak memberikan akses bagi anak didik untuk berkembang secara mandiri melalui penemuan dalam proses berpikirnya".

Untuk mengatasi hal tersebut, maka seorang guru harus mampu memilih dan menentukan model pembelajaran yang sesuai dengan materi pelajaran dan kebutuhan belajar. Ada banyak model pembelajaran yang bisa kita gunakan dalam menumbuhkembangkan kreativitas siswa, menciptakan kondisi yang menyenangkan dan menantang, mengembangkan beragam kemampuan yang bermuatan nilai, menyediakan pengalaman belajar yang beragam dan belajar melalui berbuat. Sehingga dapat meningkatkan kemampuan koneksi matematik siswa.

Salah satu model pembelajaran yang diduga akan sejalan dengan karakteristik matematika dan harapan kurikulum yang berlaku adalah pembelajaran kooperatif dan kontekstual. Surya (2009) menyatakan pembelajaran kooperatif dengan berbasis masalah dapat memecahkan masalah matematika dan kehidupan sehari-hari. Pembelajaran kooperatif adalah pembelajaran yang secara berkelompok dan tidak menekankan pada situasi pengalaman siswa. Pembelajaran ini terdiri dari: presentase kelas (materi dipresentasikan oleh guru), kelompok kerja, tes (dilakukan setelah presentasi guru dan kegiatan kelompok), peningkatan skor individu, dan penghargaan kelompok. Sedangkan pembelajaran kontekstual merupakan pembelajaran yang menekankan

Asmy Susilawaty Saragih, Sahat Saragih $\quad$ Perbedaan Kemampuan Koneksi Matematik $\quad$ Siswa Melalui Pembelajaran Kontekstual dengan Kooperatif Tipe STAD di SMP Negeri 1 Silou Kahean. Jurnal Inspiratif, Vol. 4 No. 1 April 2018 
pada belajar bermakna, dan lebih mengutamakan proses daripada hasil serta belajar dikontekskan ke dalam situasi serta pengalaman siswa. Hal ini sesuai dengan pendapat Trianto (2011:108) yang mengemukakan bahwa:

"Penerapan pembelajaran kontekstual akan sangat membantu guru untuk menghubungkan materi pelajaran dengan situasi dunia nyata dan memotivasi siswa membuat hubungan antara pengetahuan dan penerapannya dalam kehidupan mereka sebagai anggota keluarga, warga Negara, dan pekerja".

Strategi pembelajaran kontekstual lebih mengaitkan terhadap hubungan materi yang dipelajari siswa dengan kegunaan praktis dalam kehidupan sehari - hari. Kesadaran terhadap adanya kegunaan matematika dalam kehidupan sehari - hari akan meningkatkan minat siswa dalam belajar matematika dan mengurangi kebosanan siswa saat mempelajari konsep matematika . Sehingga melalui pembelajaran kontekstual diharapkan adanya peningkatan kemampuan koneksi matematik yang lebih baik. Sedangkan pembelajaran kooperatif tidak menekankan pada hubungan materi yang dipelajari siswa dengan kehidupan sehari - hari dan pengalaman siswa, sehingga diduga kemampuan koneksi matematik siswa lebih baik melalui pembelajaran kontekstual.

Dalam pembelajaran kontekstual, guru mengaitkan konten mata pelajaran dengan situasi dunia nyata siswa dan mendorong siswa membuat hubungan antara pengetahuan yang dimilikinya dengan penerapannya dalam kehidupan sehari hari, dengan melibatkan tujuh komponen utama pembelajaran kontekstual, yakni: konstruktivisme (constructivism), bertanya (questioning), inkuiri (inquiry), masyarakat belajar (learning community), pemodelan (modeling), dan penilaian autentik (authentic assessment).

Melihat besarnya kontribusi model pembelajaran kontekstual dalam pembelajaran, dapat disimpulkan bahwa model pembelajaran kontekstual merupakan salah satu alternatif pembelajaran inovatif yang berpeluang dalam mempengaruhi kemampuan koneksi matematik siswa.

\section{METODE PENELITIAN}

Dalam penelitian ini yang digunakan adalah penelitian eksperimen semu sebab kondisi-kondisi siswa tidak dapat dikontrol secara keseluruhan, seperti: persiapan siswa sebelum sekolah, pengerjaan tugas rumah, hubungan siswa dengan orang tua, hubungan siswa dengan lingkungan tempat tinggal, adanya kelas tambahan di luar sekolah dan lain sebagainya.

Penelitian ini dilaksanakan di SMP Negeri 1 Silou Kahean. Pemilihan lokasi ini berdasarkan pertimbangan bahwa di sekolah tersebut belum pernah dilakukan penelitian yang sama dengan masalah yang akan diteliti. Waktu pelaksanaan penelitian yaitu pada semester genap tahun 2015 tepatnya pada tanggal 14 April - 24 April 2015

Populasi dalam penelitian ini adalah seluruh siswa kelas VII di SMP Negeri 1 Silou Kahean tahun pelajaran 2014/2015 yang terdiri dari 5 kelas parallel, masing masing berjumlah rata - rata 34 orang. Teknik pengambilan sampel dilakukan dengan cara teknik sampel kelas acak (cluster random sampling) dengan alasan kemampuan siswa di semua kelas bersifat homogen. Satu kelas diajarkan dengan model pembelajaran CTL (Contextual Teaching and Learning), selanjutnya disebut kelas eksperimen I dan satu kelas lainnya diajarkan dengan model pembelajaran kooperatif tipe STAD, selanjutnya disebut sebagai kelas

Asmy Susilawaty Saragih, $\quad$ Sahat $\quad$ Saragih $\quad$ Perbedaan Kemampuan Koneksi Matematik $\quad$ Siswa Melalui Pembelajaran Kontekstual dengan Kooperatif Tipe STAD di SMP Negeri 1 Silou Kahean. Jurnal Inspiratif, Vol. 4 No. 1 April 2018 
eksperimen II. Dengan teknik pengambilan sampel tersebut didapat Kelas VII-3 sebagai kelas eksperimen I dan Kelas VII-4 sebagai kelas eksperimen II.

Untuk memperoleh data yang dibutuhkan maka peneliti melakukan prosedur penelitian sebagai berikut:

1. Tahap Persiapan, mencakup:

a) Menentukan tempat dan memberikan informasi kepada pihak sekolah tentang perihal kegiatan penelitian

b) Menyusun jadwal pelaksanaan penelitian disesuaikan dengan jadwal yang ada di sekolah.

c) Menyusun program dan rencana pelaksanaan pembelajaran (RPP) untuk kelas eskperimen I dengan menggunakan model pembelajaran kontekstual pada materi bangun datar segi empat. Rencana pembelajaran dibuat dalam dua kali pertemuan, dimana sekali pertemuan adalah dua kali 40 menit ( 2 x 40 menit).

d) Menyusun program dan rencana pelaksanaan pembelajaran (RPP) untuk kelas eksperimen II dengan menggunakan model pembelajaran kooperatif tipe STAD pada bangun datar segi empat. Rencana pembelajaran dibuat dalam dua kali pertemuan, dimana sekali pertemuan adalah dua kali 40 menit $(2 \times 40$ menit).

e) Menyiapkan instrumen tes (alat pengumpulan data) berupa pre-test dan post-test.

f) Memvalidkan soal instrumen penelitian.

2. Pada Tahap Pelaksanaan, mencakup:

a) Sampel dalam penelitian ini diambil dua kelas yaitu satu kelas dijadikan kelas eksperimen I dan satu kelas yang lain dijadikan kelas eksperimen II . b) Melaksanakan pretes kepada kedua kelas.

c) Mengolah data pretes.

d) Memberikan perlakuan kepada kedua kelas yaitu dengan mengadakan pembelajaran dengan bahan dan waktu yang sama hanya model pembelajaran yang berbeda. Pada kelas eksperimen I diberi perlakuan dengan model pembelajaran kontekstual dan pada kelas eksperimen II diberi perlakuan dengan model pembelajaran kooperatif tipe STAD.

e) Memberikan post-test (kepada kedua kelas untuk pengembangan kompetensi matematika siswa sesudah pembelajaran. Waktu dan lama pelaksanaan post-test pada kedua kelas adalah sama.

f) Melakukan analisis data dan uji hipotesis

g) Menyimpulkan hasil penelitian.

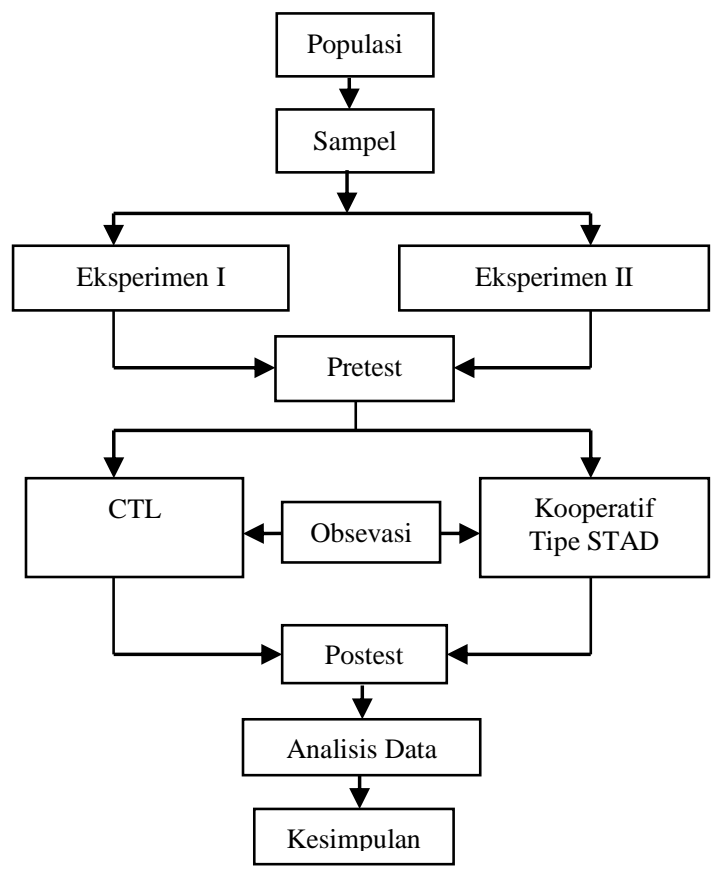

Gambar 1. Skema prosedur penelitian

Penelitian ini menggunakan dua jenis instrumen, yaitu tes dan non tes. Untuk mengungkap data kemampuan

Asmy $\quad$ Susilawaty $\quad$ Saragih, Sahat Saragih ${ }^{\circ}$ Perbedaan Kemampuan Koneksi Matematik Siswa Melalui Pembelajaran Kontekstual dengan Kooperatif Tipe STAD di SMP Negeri 1 Silou Kahean. Jurnal Inspiratif, Vol. 4 No. 1 April 2018 
koneksi matematik tes yang diberikan berbentuk uraian (essay), karena dengan bentuk uraian akan terlihat strategi siswa dalam menyelesaikan permasalahan. Selain itu bertujuan mengetahui proses penyelesaian dan ketelitian siswa dalam menjawab soal. Adapun tes yang diberikan adalah :

a. Pretes (Tes Awal)
Tes ini digunakan untuk mengukur kemampuan awal siswa terhadap materi yang akan diajarkan (materi prasyarat).

b. Postes ( Tes Kemapuan Koneksi Matematik)

Tes ini digunakan untuk mengukur kemampuan koneksi matematik siswa terhadap materi yang telah dipelajari.

Tabel 1. Kriteria Penskoran Koneksi Matematika

\begin{tabular}{|c|c|c|}
\hline $\begin{array}{l}\text { Aspek yang } \\
\text { dinilai }\end{array}$ & Skor & Keterangan \\
\hline \multirow{4}{*}{$\begin{array}{l}\text { Mengenali dan } \\
\text { menggunakan } \\
\text { koneksi antar } \\
\text { topik } \\
\text { matematika }\end{array}$} & $\mathbf{0}$ & Tidak menjawab soal sama sekali \\
\hline & 1 & $\begin{array}{l}\text { Menghubungkan informasi dalam soal dengan materi sebelumnya tetapi } \\
\text { belum benar }\end{array}$ \\
\hline & 2 & $\begin{array}{l}\text { Menghubungkan informasi dalam soal dengan materi sebelumnya } \\
\text { dengan benar tetapi jawaban masih salah }\end{array}$ \\
\hline & 3 & $\begin{array}{l}\text { Menghubungkan informasi soal dan materi sebelumnya dengan benar } \\
\text { dan jawaban benar. }\end{array}$ \\
\hline \multirow{4}{*}{$\begin{array}{l}\text { Koneksi antar } \\
\text { disiplin ilmu lain }\end{array}$} & $\mathbf{0}$ & Tidak menjawab soal sama sekali \\
\hline & 1 & $\begin{array}{l}\text { Menghubungkan materi yang dipelajari dengan materi yang ada pada } \\
\text { pelajaran lain tetapi belum benar }\end{array}$ \\
\hline & 2 & $\begin{array}{l}\text { Menghubungkan materi yang dipelajari dengan materi yang ada pada } \\
\text { pelajaran lain dengan benar tetapi penyelesaian soal belum benar }\end{array}$ \\
\hline & 3 & $\begin{array}{l}\text { Menghubungkan materi yang dipelajari dengan materi yang ada pada } \\
\text { pelajaran lain dengan benar tetapi penyelesaian soal benar }\end{array}$ \\
\hline \multirow{4}{*}{$\begin{array}{l}\text { Dengan } \\
\text { kehidupan } \\
\text { sehari - hari }\end{array}$} & $\mathbf{0}$ & Tidak menjawab soal sama sekali \\
\hline & 1 & $\begin{array}{l}\text { Menghubungkan masalah kehidupan nyata pada soal ke dalam materi } \\
\text { yang dipelajari, tetapi belum benar }\end{array}$ \\
\hline & 2 & $\begin{array}{l}\text { Menghubungkan masalah kehidupan nyata pada soal ke dalam materi } \\
\text { yang dipelajari dengan benar, tetapi penyelesaian belum benar }\end{array}$ \\
\hline & 3 & $\begin{array}{l}\text { Menghubungkan masalah kehidupan nyata pada soal ke dalam materi } \\
\text { yang dipelajari dan penyelesaian benar. }\end{array}$ \\
\hline
\end{tabular}

Penentuan tingkat kemampuan koneksi Pedoman yang digunakan adalah sebagai berikut : matematik siswa dengan menggunakan rumus sebagai berikut :

$$
N K K M=\frac{\text { Skor yang diperoleh siswa }}{\text { Skor maksimum }} \times 100
$$

Tabel 2. Kategori Penilaian

\begin{tabular}{|l|l|}
\hline Rentang Nilai & Kategori \\
\hline $0 \leq$ NKKM $<65$ & Kurang \\
\hline $65 \leq$ NKKM $<75$ & Cukup \\
\hline $75 \leq$ NKKM $<90$ & Baik \\
\hline $90 \leq$ NKKM $\leq 100$ & Sangat Baik \\
\hline
\end{tabular}

Asmy $\quad$ Susilawaty $\quad$ Saragih, Sahat Saragih $^{-}$Perbedaan Kemampuan Koneksi Matematik $\quad$ Siswa Melalui Pembelajaran Kontekstual dengan Kooperatif Tipe STAD di SMP Negeri 1 Silou Kahean. Jurnal Inspiratif, Vol. 4 No. 1 April 2018 
Sedangkan untuk kriteria proses jawaban tabel 3 yaitu sebagai berikut:

kemampuan koneksi matematik digunakan

Tabel 3. Indikator Proses Jawaban

\begin{tabular}{|l|l|c|c|}
\hline $\begin{array}{c}\text { Kemampuan } \\
\text { Koneksi } \\
\text { Matematik }\end{array}$ & \multicolumn{1}{|c|}{$\begin{array}{c}\text { Indikator Proses } \\
\text { Jawaban Siswa }\end{array}$} & $\begin{array}{c}\text { Interval } \\
\text { Nilai }\end{array}$ & $\begin{array}{c}\text { Kategori } \\
\text { Penilaian }\end{array}$ \\
\hline $\begin{array}{l}\text { Antar topik } \\
\text { matematika }\end{array}$ & $\begin{array}{l}\text { Langkah penyelesaian lengkap dan } \\
\text { jawaban benar }\end{array}$ & $2<\mathrm{x} \leq 3$ & Baik \\
$\begin{array}{l}\text { Dengan disiplin } \\
\text { ilmu lain }\end{array}$ & $\begin{array}{l}\text { Langkah penyelesaian tidak lengkap } \\
\text { dan jawaban benar }\end{array}$ & $1<\mathrm{x} \leq 2$ & Cukup \\
$\begin{array}{l}\text { Dengan } \\
\text { kehidupan } \\
\text { sehari - hari }\end{array}$ & $\begin{array}{l}\text { Langkah penyelesaian lengkap tapi } \\
\text { jawaban tidak benaf }\end{array}$ & $0<\mathrm{x} \leq 1$ & Kurang \\
\hline
\end{tabular}

\section{Teknik Analisis Data}

Teknik analisis data yang digunakan adalah Teknik Statistik Deskriptif dan Inferensial. Teknik statistic deskriptif digunakan untuk mendeskriptifkan data antara lain: nilai minimum, maksimum, jumlah, rata-rata (mean), standar deviasi (sd) dan varians teknik. Statistika inferensial digunakan untuk menguji hipotesis penelitian, dimana teknik inferensial yang digunakan dalam penelitian ini adalah uji-t. Sebelum menggunakan teknik ini, terlebih dahulu ditentukan persyaratan analisis data yakni persyaratan Normalitas dan Homogenitas.

\section{Untuk Menghitung Mean}

Untuk menghitung nilai rata-rata digunakan rumus (Sudjana, 2009:67), yaitu:

$$
\bar{X}=\frac{\sum x_{i}}{n}
$$

Keterangan:

$\overline{\mathrm{X}}=$ Mean / rata - rata untuk sampel

$\mathrm{x}_{\mathrm{i}}=$ Nilai data

$\mathrm{n}=$ banyak data

\section{Untuk Menghitung Simpangan Baku}

Untuk menghitung simpangan baku (s) digunakan rumus (Sudjana, 2009: 94), yaitu:

$$
s=\sqrt{\frac{n \sum x^{2}-\left(\sum x i\right)^{2}}{n(n-1)}}
$$

Keterangan:

$\mathrm{s}=$ Simpangan baku

$\mathrm{x}_{\mathrm{i}}=$ Nilai data kelas ke $\mathrm{i}$

$\mathrm{n}=$ banyak data

\section{Untuk Menghitung Varians}

Untuk menghitung varians $\left(\mathrm{s}^{2}\right)$ digunakan rumus (Sudjana, 2009: 94), yaitu:

$$
\mathrm{s}^{2}=\frac{\mathrm{n} \sum \mathrm{xi}^{2}-\left(\sum \mathrm{xi}\right)^{2}}{\mathrm{n}(\mathrm{n}-1)}
$$

Keterangan:

$\mathrm{s}^{2}=$ Varians

$\mathrm{x}_{\mathrm{i}}=$ Nilai data kelas ke $\mathrm{i}$

$\mathrm{n}=$ banyak data

\section{Uji Normalitas}

Uji ini bertujuan untuk melihat apakah sampel berdistribusi normal atau tidak. Uji yang digunakan adalah liliefors dengan langkah-langkah (Sudjana, 2009 : 466) sebagai berikut :

1. Menyusun skor siswa dari yang tertinggi ke skor yang terendah.

2. Skor mentah dijadikan bilangan $\mathrm{z}_{1}, \mathrm{z}_{2}$, $\mathrm{z}_{3}, \ldots, \mathrm{z}_{\mathrm{n}}$ dengan rumus :

$$
z_{i}=\frac{x_{i}-\bar{x}}{s}
$$

Dengan:

Asmy Susilawaty Saragih, Sahat Saragih $\quad$ Perbedaan Kemampuan Koneksi Matematik Siswa Melalui Pembelajaran Kontekstual dengan Kooperatif Tipe STAD di SMP Negeri 1 Silou Kahean. Jurnal Inspiratif, Vol. 4 No. 1 April 2018 


$$
\begin{aligned}
& \mathrm{z}_{\mathrm{i}}=\mathrm{z} \text { skor pada kelas ke } \mathrm{i} \\
& \mathrm{x}_{\mathrm{i}}=\text { data tabel ke }-\mathrm{i} \\
& \overline{\mathrm{x}}=\text { rata }- \text { rata hitung } \\
& \mathrm{s}=\text { simpangan baku }
\end{aligned}
$$

3. Untuk tiap bilangan ini menggunakan daftar disribusi normal kumulatif, kemudian dihitung peluang $F\left(z_{i}\right)=$ $P\left(z \leq z_{i}\right)$

4. Selanjutnya dihitung proporsi $z_{1}, z_{2}, z_{3}$, $\ldots, z_{n}$ yang lebih kecil atau sama dengan $z_{i}$. Jika proporsi ini dinyatakan dengan $\mathrm{S}\left(\mathrm{z}_{\mathrm{i}}\right)$ maka :

$$
\begin{aligned}
& \mathrm{S}(\mathrm{zi}) \\
& =\frac{\text { banyaknya } \mathrm{z}_{1}, \mathrm{z}_{2}, \mathrm{z}_{3}, \ldots, \mathrm{z}_{\mathrm{n}} \text { yang } \leq \mathrm{z}_{\mathrm{i}}}{\mathrm{n}}
\end{aligned}
$$

5. Menghitung selisih $F\left(z_{i}\right)-\mathrm{S}(\mathrm{zi})$, kemudian ditentukan harga mutlaknya yang terbesar dinyatakan dengan $\mathrm{L}_{\mathrm{o}}$.

Untuk menerima atau menolak hipotesis nol, kita bandingkan $\mathrm{L}_{\mathrm{o}}$ ini dengan nilai kritis $\mathrm{L}$ dari tabel uji Lilliefors dengan taraf nyata $\alpha=0,05$ dengan criteria sebagai berikut :

$\mathrm{L}_{0} \leq \mathrm{L}_{\text {tabel }}$

$=$ sampel berdistribusi normal

$\mathrm{L}_{0} \geq \mathrm{L}_{\text {tabel }}$

$=$ sampel tidak berdistribusi normal.

\section{Uji Homogenitas}

Jika dalam uji normalitas diperoleh data berdistribusi normal, maka selanjutnya dilakukan uji homogenitas. Misalkan dua populasi normal dengan varians $\sigma_{1}^{2}$ dan $\sigma_{2}^{2}$ akan diuji dua pihak untuk pasangan hipotesis

nol.

$\mathrm{H}_{0}$ dan tandingannya $\mathrm{H}_{\mathrm{a}}$ (Sudjana, 2009 : 249).

$$
\left\{\begin{array}{l}
H_{0}: \sigma_{1}^{2}=\sigma_{2}^{2} \\
H_{a}: \sigma_{1}^{2} \neq \sigma_{2}^{2}
\end{array}\right.
$$

Berdasarkan sampel acak yang masingmasing secara independent diambil dari populasi tersebut. Jika sampel dari populasi kesatu berukuran $n_{1}$ dengan varians $s_{1}^{2}$ dan sampel dari populasi $\mathrm{n}_{2}$ dengan varians $\mathrm{s}_{2}^{2}$ maka untuk menguji hipotesis di atas digunakan statistik:

$$
\mathrm{F}=\frac{\text { varians terbesar }}{\text { varians terkecil }}
$$

Dengan kriteria sebagai berikut:

$$
\begin{aligned}
\text { a. Jika } \mathrm{F}_{\text {hitung }}> & F_{\text {tabel }} \\
& =\mathrm{H}_{0} \text { diterima } \\
\text { b. Jika } \mathrm{F}_{\text {hitung }}< & \mathrm{F}_{\text {tabel }} \\
& =\mathrm{H}_{0} \text { ditolak }
\end{aligned}
$$

Dimana $F_{\text {tabel }}$ merupakan $F_{\alpha\left(v_{1}, v_{2}\right)}$ dapat dilihat pada daftar distribusi $F$ dengan peluang $\alpha$,dimana

$\mathrm{v}_{1}$ merupakan $\mathrm{dk}_{\text {pembilang }}=$ $\left(\mathrm{n}_{1}-1\right)$ dan $\mathrm{v}_{2}$ merupakan $\mathrm{dk}_{\text {penyebut }}=$ $\left(n_{2}-1\right)$ dengan taraf $\alpha=0,05$

\section{Uji Hipotesis Penelitian}

Berdasarkan hipotesis penelitian yang telah dirumuskan pada bagian terdahulu, pengaruh model pembelajaran dapat dilihat dari perbedaan kemampuan pemecahan masalah matematik siswa yang mengikuti pendekatan Quantum learning dengan siswa yang mengikuti model pembelajaran Kooperatif Tipe STAD. Teknik analasis data yang digunakan adalah analisis perbedaan dengan menggunakan statistik uji-t, karena berdasarkan analisis data, diperoleh data kedua kelompok berdistribusi normal dan varians homogen. Hipotesis yang akan diuji adalah :

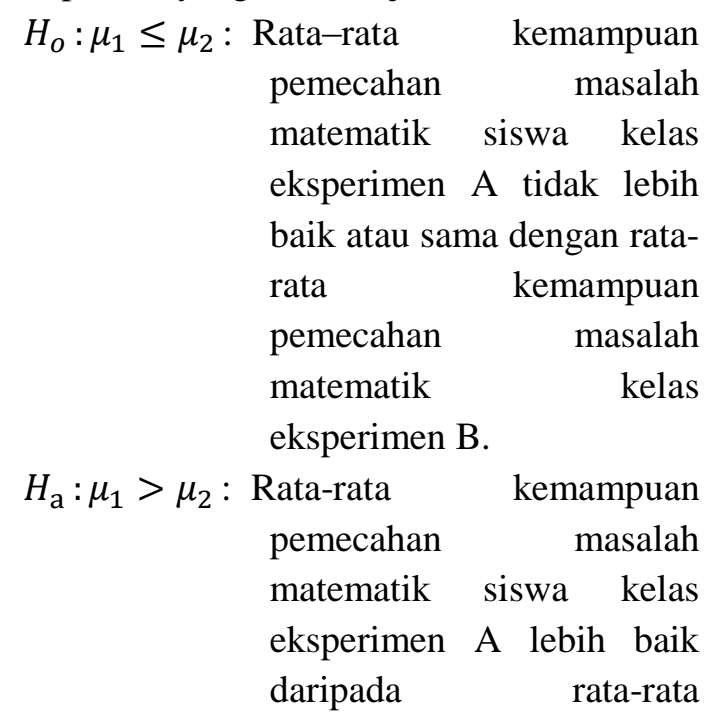

Asmy $\quad$ Susilawaty $\quad$ Saragih, $\quad$ Sahat $\quad$ Saragih $^{\circ}$ Perbedaan Kemampuan Koneksi Matematik $\quad$ Siswa Melalui Pembelajaran Kontekstual dengan Kooperatif Tipe STAD di SMP Negeri 1 Silou Kahean. Jurnal Inspiratif, Vol. 4 No. 1 April 2018 


\author{
kemampuan pemecahan \\ masalah kelas eksperimen \\ B.
}

Keterangan:

$\mu_{1}=$ Rerata skor kemampuan pemecahan masalah matematik siswa yang diajarkan dengan pendekatan Quantum Learning.

$\mu_{2}=$ Rerata skor kemampuan pemecahan masalah matematik siswa yang diajarkan dengan model pembelajaran kooperatif tipe STAD

Adapun rumus statistik uji $\mathrm{t}$ adalah sebagai berikut:

$t=\frac{\bar{x}_{1}-\bar{x}_{2}}{s \sqrt{\left(\frac{1}{n_{1}}\right)+\left(\frac{1}{n_{2}}\right)}}($ Sudjana, 2009:241)

Keterangan:

$n_{1}=$ Jumlah sampel kelas eksperimen A

$n_{2}=$ Jumlah sampel kelas eksperimen B

$s^{2}=$ Variansi gabungan

$\bar{x}_{1}=$ Skor rata - rata kelas eksperimen A

$\bar{x}_{2}=$ Skor rata - rata kelas eksperimen $\mathrm{B}$

Kriteria pengujian yang berlaku ialah: terima $H_{0}$ jika $-t_{1-\frac{1}{2} \alpha}<t_{\text {hitung }}<t_{1-\frac{1}{2} \alpha}$ dan tolak $H_{0}$ jika mempunyai harga-harga lain. Derajat kebebasan untuk daftar distribusi $\mathrm{t}$ ialah $\left(n_{1}+n_{2}-2\right)$ dengan peluang $\left(1-\frac{1}{2} \alpha\right)$ pada taraf signifikan $\alpha=0,05$.

\section{Defenisi Operasional}

1. Kemampuan koneksi matematika siswa adalah kemampuan siswa menghubungkan konsep matematika, memahami antar topik matematika, menggunakan matematika dalam bidang studi lain ataupun kehidupan sehari-hari.

2. Model pembelajaran kontekstual atau Contextual Teaching and Learning (CTL) adalah strategi yang menekankan pada proses keterlibatan siswa secara penuh untuk dapat menemukan materi yang dipelajari, mendorong siswa agar dapat menemukan hubungan antara materi yang dipelajari dengan situasi kehidupan nyata dan mendorong siswa untuk dapat menerapkannya dalam kehidupan. Ada tujuh prinsip pembelajaran kontekstual yang harus dikembangkan oleh guru, yaitu
a. Konstruktivisme (Constructivism)
b. Menemukan (Inquiry)
c. Bertanya (Questioning)
d. Masyarakat belajar (Learning Community)
e. Pemodelan (Modelling)
f. Refleksi (Reflection)
g. Penilaian sebenarnya (Autentic Assesment)

3. Model pembelajaran kooperatif adalah pembelajaran yang melibatkan kelompok kecil, untuk bekerjasama dalam memecahkan masalah, menyelesaikan tugas untuk mencapai tujuan bersama dan akhirnya dapat meningkatkan prestasi hasil belajar bersama - sama pula.

4. Model pembelajaran kontekstual dikatakan berpengaruh terhadap kemampuan koneksi matematik siswa jika terdapat perbedaan yang signifikan antara pembelajaran kontekstual dengan pembelajaran kooperatif.

5. Proses jawaban siswa adalah kesistematisan jawaban siswa dari tes kemampuan koneksi matematik. Dengan ide - ide yang berbeda,

6. maka proses jawaban pun akan bervariasi. Proses jawaban siswa diukur dengan kriteria lengkap ataupun tidak lengkap sesuai dengan rubrik kemampuan koneksi matematik. Hal ini dapat terlihat dari lembar jawaban siswa dalam menyelesaikan tes kemampuan koneksi matematik.

\section{HASIL DAN PEMBAHASAN}

Data yang dianalisis adalah tes kemampuan koneksi matematik dan proses

Asmy $\quad$ Susilawaty $\quad$ Saragih, Sahat Saragih ${ }^{\circ}$ Perbedaan Kemampuan Koneksi Matematik Siswa Melalui Pembelajaran Kontekstual dengan Kooperatif Tipe STAD di SMP Negeri 1 Silou Kahean. Jurnal Inspiratif, Vol. 4 No. 1 April 2018 
jawaban siswa. Hasil tes tersebut memberikan informasi tentang kemampuan siswa sebelum dan sesudah dilakukan proses pembelajaran baik di kelas eksperimen I dengan pembelajaran kontekstual (CTL) maupun di kelas eksperimen II dengan pembelajaran kooperatif tipe STAD.

\section{Hasil Tes Kemampuan Awal Matematik (KAM)}

Tes kemampuan awal matematik (KAM) digunakan untuk mengetahui kesetaraan rerata kelompok eksperimen I dan kelompok eksperimen II, dan untuk mengelompokkan siswa berdasarkan KAM yaitu sangat baik, baik, cukup, dan kurang. Untuk mencapai tujuan tersebut, peneliti memberikan soal materi prasyarat yang terdiri dari 3 soal.

Data diperoleh dari 68 siswa, terdiri dari 34 orang siswa pada kelompok yang mendapat pembelajaran Kontekstual (kelompok eksperimen I) dan 34 orang siswa yang mendapat pembelajaran Kooperatif Tipe STAD (kelompok eksperimen II). Untuk memperoleh gambaran terhadap kemampuan awal siswa (KAM) data dianalisis secara deskriptif. Dari hasil pemberian tes diperoleh rata rata kemampuan awal kelas eksperimen I 63,205 dan kelas ekpserimen II 61,5. Secara ringkas disajikan rangkuman hasil analisis deskriptif data KAM siswa berdasarkan pembelajaran disajikan pada tabel berikut:

Tabel 4. Rekapitulasi Tes KAM Kelas Eksperimen I dan Eksperimen II

\begin{tabular}{|c|c|c|c|c|c|c|}
\hline Sampel & $\mathbf{N}$ & $\begin{array}{c}\text { Data } \\
\text { Terendah }\end{array}$ & $\begin{array}{c}\text { Data } \\
\text { Tertinggi }\end{array}$ & $\begin{array}{c}\text { Rata - } \\
\text { rata }\end{array}$ & Varians & $\begin{array}{c}\text { Standar } \\
\text { Deviasi }\end{array}$ \\
\hline Kelas Eksperimen I & 34 & 22 & 89 & 63,529 & 399,166 & 19,98 \\
\hline Kelas Eksperimen II & 34 & 22 & 89 & 61,5 & 511,167 & 22,609 \\
\hline
\end{tabular}

Berdasarkan rata - rata tes kemampuan awal kedua kelas, terlihat bahwa kelas eksperimen I dan kelas eksperimen II memiliki rata - rata yang masih tergolong rendah (kurang), sehingga penelitian perlu dilanjutkan. Peneliti mengajar di kelas eksperimen I dan di kelas eksperimen II. Pada kelas ekpserimen I diberikan model pembelajaran kontekstual sedangkan pada kelas eksperimen II diberikan model pembelajaran kooperatif tipe STAD. Siswa dibentuk pada 8 kelompok yang terdiri dari $4-5$ orang.

Dari nilai rata-rata sampel diatas dapat dilakukan uji hipotesis dan diperoleh bahwa tidak ada perbedaan antara kemampuan awal kedua kelas tersebut. Perhitungan selanjutnya terdapat pada lampiran. Berdasarkan data tersebut penelitian perlu dilanjutkan untuk memperoleh gambaran setelah penelitian berakhir.

\section{Nilai Kemampuan Koneksi Matematik (Postes)}

Berdasarkan hasil tes kemampuan awal matematik siswa yang relatif sama, selanjutnya dilakukan pembelajaran yang berbeda pada kedua kelas masing - masing 2 pertemuan, yaitu pada kelas eksperimen I diterapkan pembelajaran kontekstual sementara pada kelas ekpserimen II diterapkan pembelajaran kooperatif tipe STAD.

Pada akhir pertemuan, siswa diberikan tes (postes). Tujuan diadakannya postes adalah untuk mengetahui kemampuan

Asmy $\quad$ Susilawaty $\quad$ Saragih, $\quad$ Sahat $\quad$ Saragih $^{\circ} \quad$ Perbedaan Kemampuan Koneksi Matematik $\quad$ Siswa $\quad$ Melalui Pembelajaran Kontekstual dengan Kooperatif Tipe STAD di SMP Negeri 1 Silou Kahean. Jurnal Inspiratif, Vol. 4 No. 1 April 2018 
koneksi matematik siswa dari kedua kelas.

kedua kelompok pada tabel 5. berikut :

Secara ringkas disajikan tabel hasil postes

Tabel 5. Rekapitulasi Postes Kelas Eksperimen I dan Eksperimen II

\begin{tabular}{|c|c|c|c|c|c|c|}
\hline Sampel & N & $\begin{array}{c}\text { Data } \\
\text { Terendah }\end{array}$ & $\begin{array}{c}\text { Data } \\
\text { Tertinggi }\end{array}$ & $\begin{array}{c}\text { Rata - } \\
\text { rata }\end{array}$ & Varians & $\begin{array}{c}\text { Standar } \\
\text { Deviasi }\end{array}$ \\
\hline Kelas Eksperimen I & 34 & 67 & 100 & 84,471 & 140,196 & 11,84 \\
\hline Kelas Eksperimen II & 34 & 33 & 100 & 77,029 & 186,029 & 13,639 \\
\hline
\end{tabular}

Bila diperhatikan pada tabel di atas dapat dilihat rata - rata postes kelas eksperimen I 84,471 dari 34 orang siswa dan kelas eksperimen II 77,029 dari 34 orang siswa. Dari hasil postes, diperoleh perbedaan rata - rata pada kedua kelompok. Pada kelompok eksperimen I dengan menggunakan model pembelajaran kontekstual dalam pembelajaran, nilai rata - rata postes lebih tinggi dibandingkan nilai rata - rata postes kelompok kontrol dengan menggunakan pembelajaran kooperatif tipe STAD.

Secara deskriptif kesimpulan yang diperoleh berkenaan dengan kemampuan koneksi matematik yaitu: rata - rata postes kemampuan koneksi matematik kelas eksperimen I $(84,471)$ lebih tinggi dibandingkan dengan rata - rata postes kemampuan koneksi matematik kelas eksperimen II $(77,029)$.

Untuk mengetahui signifikansi kesimpulan di atas perlu dilakukan perhitungan pengujian statistik. Untuk menguji perbedaan rata - rata kedua kelas, digunakan uji t. Deskripsi hasil analisisnya disajikan pada sub bab berikut ini.

\section{Analisis Data Hasil Penelitian}

\section{Uji Normalitas Data}

Hasil perhitungan uji normalitas data pretes dan postes di kelas eksperimen I dan kelas eksperimen II dapat dilihat berikut:

\section{Tabel 6. Hasil Uji Normalitas Kelas Eksperimen I dan Eksperimen II}

\begin{tabular}{|c|c|l|c|c|c|}
\hline No & Data & \multicolumn{1}{|c|}{ Kelas } & $\mathbf{L}_{\mathbf{0}}$ & $\mathbf{L}_{\text {tabel }}$ & Kesimpulan \\
\hline 1 & Pretes & Eksperimen I (VII-3) & 0,109 & 0,152 & Normal \\
\hline 2 & Pretes & Eksperimen II (VII-4) & 0,1112 & 0,152 & Normal \\
\hline 3 & Postes & Eksperimen I (VII-3) & 0,1499 & 0,152 & Normal \\
\hline 4 & Postes & Eksperimen II (VII-4) & 0,1486 & 0,152 & Normal \\
\hline
\end{tabular}

Berdasarkan tabel di atas diperoleh bahwa data pretes dan postes kelas eksperimen I dan kelas eksperimen II untuk kedua uji, memiliki nilai $\mathrm{L}_{0}$ yang lebih kecil dari $\mathrm{L}_{\text {tabel }}$ yaitu data pretes untuk kelas eksperimen I $(0,109<0,152)$, sementara untuk kelas eksperimen II $(0,1112<0,152)$. Sedangkan untuk data postes, kelas eksperimen I $(0,1499<0,152)$ dan untuk kelas eksperimen II $(0,1486<0,152)$. Maka dapat disimpulkan data pretes dan postes model pembelajaran kontekstual dan kooperatif tipe STAD berdistribusi normal.

\section{Uji Homogenitas}

Untuk menguji homogenitas sampel digunakan uji kesamaan varians. Syarat data homogen adalah $\mathrm{F}_{\text {hitung }}<\mathrm{F}_{\text {tabel }}$ pada taraf nyata 0,05 serta $\quad \mathrm{dk}=\left(\mathrm{v}_{1}, \mathrm{v}_{2}\right)$ dimana $\quad \mathrm{v}_{1}=\mathrm{n}_{1}-1$ dan $\mathrm{v}_{2}=\mathrm{n}_{2}-1$. Secara ringkas hasil perhitungan uji homogenitas antara kelompok eksperimen I dan kelompok eksperimen II tampak pada tabel

Asmy $\quad$ Susilawaty $\quad$ Saragih, $\quad$ Sahat $\quad$ Saragih $^{\circ}$ Perbedaan Kemampuan Koneksi Matematik $\quad$ Siswa $\quad$ Melalui Pembelajaran Kontekstual dengan Kooperatif Tipe STAD di SMP Negeri 1 Silou Kahean. Jurnal Inspiratif, Vol. 4 No. 1 April 2018 
Tabel 7. Hasil Uji Homogenitas Pretes dan Postes Kelompok Eksperimen I dan Eksperimen II

\begin{tabular}{|c|l|c|c|c|}
\hline No & Data & $\mathbf{F}_{\text {hitung }}$ & $\mathbf{F}_{\text {tabel }}$ & Kesimpulan \\
\hline 1 & Pretes kelas eksperimen I dan eksperimen II & 1,281 & 1,802 & Homogen \\
\hline 2 & Postes kelas eksperimen I dan eksperimen II & 1,327 & 1,802 & Homogen \\
\hline
\end{tabular}

Dari tabel di atas dapat dilihat bahwa data pretes dan postes memiliki nilai $\mathrm{F}_{\text {hitung }}<\mathrm{F}_{\text {tabel }}$ yaitu untuk data pretes $(1,281<1,802)$ dan untuk data postes $(1,327<1,802)$. Hal ini menunjukkan bahwa kedua data sampel memiliki varians yang sama (homogen).

Berdasarkan tabel 4.11. dan tabel 4.12. maka kesimpulannya adalah bahwa data penelitian telah memenuhi syarat untuk dilakukan uji hipotesis.

\section{Uji Hipotesis}

Kriteria pengujian jika $t_{\text {hitung }}<t_{\text {tabel }}$ maka $\mathrm{H}_{0}$ diterima sedangkan $\mathrm{H}_{1}$ ditolak. Sebaliknya jika $t_{\text {hitung }}>t_{\text {tabel }}$ maka $\mathrm{H}_{0}$ ditolak sedangkan $\mathrm{H}_{1}$ diterima. Hasil perhitungan uji-t terhadap pretes dan postes dapat dilihat pada tabel berikut:

Tabel 8. Hasil Uji Hipotesis

\begin{tabular}{|l|c|c|c|c|c|}
\hline \multirow{2}{*}{ Data } & \multicolumn{2}{|c|}{ Rata - rata } & \multirow{2}{*}{$\mathbf{t}_{\text {hitung }}$} & $\mathbf{t}_{\text {tabel }}$ & Kesimpulan \\
\cline { 2 - 3 } & Eks I & Eks II & & & \\
\hline Pretes & 63,529 & 61,5 & 0,391 & 1,671 & Tidak ada perbedaan \\
\hline Postes & 84,471 & 77,029 & 2,398 & 1,669 & Ada perbedaan \\
\hline
\end{tabular}

Berdasarkan tabel di atas dapat disimpulkan bahwa $t_{\text {hitung }}<t_{\text {tabel }}$ pada data pretes berarti rata - rata kemampuan awal siswa di kedua kelompok adalah sama. Sedangkan untuk postes nilai $t_{\text {hitung }}=$ 2,398

sedangkan $t_{\text {tabel }} 1,669$. Hal ini menunjukka $n$ bahwa nilai $t_{\text {hitung }}>t_{\text {tabel }}$ sehingga $H_{0}$ ditolak, maka dapat diambil kesimpulan bahwa kemampuan koneksi matematik siswa yang mendapatkan pembelajaran
CTL (Kontekstual) lebih tinggi daripada siswa yang mendapat pembelajaran kooperatif tipe STAD.

\section{Analisis Proses Jawaban Siswa}

Rekapitulasi proses jawaban siswa pada masing - masing butir soal kelas eksperimen I dan kelas eksperimen II adalah sebagai berikut:

Asmy Susilawaty Saragih, Sahat Saragih Perbedaan Kemampuan Koneksi Matematik Siswa Melalui Pembelajaran Kontekstual dengan Kooperatif Tipe STAD di SMP Negeri 1 Silou Kahean. Jurnal Inspiratif, Vol. 4 No. 1 April 2018 
Tabel 9. Skor Butir Soal proses Jawaban Kemampuan Koneksi Matematik

\begin{tabular}{|c|c|c|c|c|c|c|c|}
\hline \multirow{3}{*}{ No } & \multirow[b]{3}{*}{$\begin{array}{l}\text { Aspek } \\
\text { Koneksi }\end{array}$} & \multirow[b]{3}{*}{$\begin{array}{l}\text { Kategori } \\
\text { Skor }\end{array}$} & \multirow[b]{3}{*}{$\begin{array}{l}\text { Kriteria } \\
\text { Penilaian }\end{array}$} & \multicolumn{4}{|c|}{ Kelompok } \\
\hline & & & & \multicolumn{2}{|c|}{ Eksperimen } & \multicolumn{2}{|c|}{ Kontrol } \\
\hline & & & & $\begin{array}{c}\text { Jumlah Siswa } \\
\text { dan } \\
\text { Persentase }\end{array}$ & Rerata & $\begin{array}{l}\text { Jumlah Siswa } \\
\text { dan Persentase }\end{array}$ & Rerata \\
\hline \multirow{3}{*}{1} & \multirow{3}{*}{$\begin{array}{l}\text { Antar } \\
\text { topik } \\
\text { matematik } \\
\text { a }\end{array}$} & $2<x \leq 3$ & Baik & $34(100 \%)$ & \multirow{3}{*}{3,00} & $27(79,41 \%)$ & \multirow{3}{*}{2,76} \\
\hline & & $1<x \leq 2$ & Cukup & $0(0 \%)$ & & $6(17,65 \%)$ & \\
\hline & & $0<\mathrm{x} \leq 1$ & Kurang & $0(0 \%)$ & & $1(3,235)$ & \\
\hline \multirow{3}{*}{2} & \multirow{3}{*}{$\begin{array}{l}\text { Dengan } \\
\text { disiplin } \\
\text { ilmu lain }\end{array}$} & $2<x \leq 3$ & Baik & $23(67,65 \%)$ & \multirow{3}{*}{2,68} & $24(70,59 \%)$ & \multirow{3}{*}{2,54} \\
\hline & & $1<x \leq 2$ & Cukup & $11(32,35 \%)$ & & $6(17,65 \%)$ & \\
\hline & & $0<x \leq 1$ & Kurang & $0(0 \%)$ & & $4(11,76 \%)$ & \\
\hline \multirow{4}{*}{3} & \multirow{4}{*}{$\begin{array}{l}\text { Dengan } \\
\text { kehidupan } \\
\text { sehari - } \\
\text { hari }\end{array}$} & $2<x \leq 3$ & Baik & $10(29,415)$ & \multirow{4}{*}{1,91} & $4(11,67 \%)$ & \multirow{4}{*}{1,47} \\
\hline & & $1<\mathrm{x} \leq 2$ & Cukup & $11(32,355)$ & & $10(29,41 \%)$ & \\
\hline & & $0<\mathrm{x} \leq 1$ & Kurang & $13(38,23 \%)$ & & $20(58,82 \%)$ & \\
\hline & & & & & & & \\
\hline \multicolumn{5}{|c|}{ Rata - rata } & 2,53 & & 2,26 \\
\hline
\end{tabular}

Dari tabel diatas juga dapat dilihat untuk butir soal nomor 1 rata-rata proses jawaban siswa kelas eksperimen I 3,00 dan kelas eksperimen II 2,76. Untuk butir soal nomor 2 kelas eksperimen I 2,68 dan kelas eksperimen II 2,54. Butir soal nomor 3 kelas eksperimen I 1,91 dan kelas eksperimen II 1,47 Rata-rata keseluruhan proses jawaban siswa kelas eksperimen I 2,53 (Baik) dan rata-rata keseluruhan proses jawaban kelas eksperimen II 2,26 (Baik).

\section{Pembahasan}

Kemampuan Koneksi Matematik Siswa yang Mengikuti Pembelajaran Kontekstual Lebih Tinggi Daripada Siswa yang Mengikuti Pembelajaran Kooperatif Tipe STAD.

Berdasarkan hasil penelitian diperoleh rata - rata kelas eksperimen I 84,471 dan kelas eksperimen II diperoleh rata - rata 77,029. Hal ini menunjukkan bahwa kemampuan koneksi matematik siswa yang mengikuti pembelajaran kontekstual lebih tinggi daripada siswa yang mengikuti pembelajaran kooperatif tipe STAD.

Ditinjau dari indikator kemampuan koneksi matematik siswa diperoleh bahwa siswa yang mengikuti pembelajaran dengan model pembelajaran CTL lebih meningkat dibanding dengan pembelajaran kooperatif tipe STAD, hal ini dapat dilihat dari proses jawaban siswa dimana proses jawaban siswa yang pembelajarannya dengan pembelajaran kontekstual lebih baik dibandingkan dengan siswa yang pembelajarannya dengan pembelajaran kooperatif tipe STAD.

Hal ini dikarenakan model pembelajaran CTL pada proses pembelajaran menunjukkan suasan yang interaktif serta bermakna karena belajar dikontekskan ke dalam situasi dunia nyata. Hal ini sejalan dengan Trianto (2011:108) yang mengemukakan bahwa:

"Penerapan pembelajaran kontekstual akan sangat membantu guru untuk menghubungkan materi pelajaran dengan

Asmy Susilawaty Saragih, Sahat Saragih $\quad$ Perbedaan Kemampuan Koneksi Matematik $\quad$ Siswa Melalui Pembelajaran Kontekstual dengan Kooperatif Tipe STAD di SMP Negeri 1 Silou Kahean. Jurnal Inspiratif, Vol. 4 No. 1 April 2018 
situasi dunia nyata dan memotivasi siswa membuat hubungan antara pengetahuan dan penerapannya dalam kehidupan mereka sebagai anggota keluarga, warga Negara, dan pekerja".

Teori pembelajaran Ausubel (Dahar, 2010) yang dikenal dengan teori belajar bermakna menganggap bahwa belajar bermakna adalah sebuah proses pembelajaran yang mengaitkan pengetahuan sebelumnya untuk merespon pengetahuan atau informasi baru yang akan dikuasainya. Oleh karena itu agar pembelajaran matematika bermakna bagi siswa, konsep baru yang disampaikan dalam pembelajaran harus dikaitkan dengan kehidupan nyata siswa. Dengan kata lain materi yang diajarkan pada siswa harus mempunyai keterkaitan dengan dunia nyata siswa.

Hasil penelitian ini juga didukung oleh hasil penelitian terdahulu yang dilakukan Rosliana (2012) yang menyatakan bahwa secara signifikan kemampuan koneksi matematik siswa melalui pembelajaran kontekstual lebih baik daripada kemampuan koneksi matematik siswa melalui pembelajaran kooperatif tipe STAD. Hal ini juga sejalan dengan temuan Surya, dkk. (2013) yang menemukan pembelajaran dengan pendekatan kontekstual meningkatkan kemampuan matematika pada siswa dengan kategori awal tinggi, sedang, dan rendah dibandingkan dengan pendekatan konvensional.

Dari pembahasan di atas, adanya penelitian yang relevan, teori belajar yang mendukung dan keunggulan - keunggulan yang peneliti jelaskan di atas ditemukan bahwa kemampuan koneksi matematik yang diajar dengan model pembelajaran kontekstual lebih tinggi secara signifikan daripada siswa yang diajar dengan model pembelajaran kooperatif tipe STAD. Hal ini membuktikan bahwa terdapat perbedaan kemampuan koneksi matematik siswa melalui model pembelajaran kontekstual dan kooperatif tipe STAD

\section{Proses Jawaban Siswa}

Kemampuan koneksi matematik terbagi atas tiga bagian yaitu koneksi antartopik matematika, koneksi matematika dengan disiplin ilmu lain, dan koneksi matematika dengan kehidupan sehari - hari. Dengan melihat lembar jawaban siswa terdapat variasi jawaban antara kelas eksperimen I dengan kelas eksperimen II. Untuk butir soal nomor 1 siswa yang diajar dengan model pembelajaran kontekstual secara umum menuliskan jawaban secara lengkap dan benar, sedangkan siswa yang diajar dengan model pembelajaran kooperatif tipe STAD masih ada dijumpai yang menuliskan jawaban tidak lengkap serta tidak benar.

Butir soal nomor 2, siswa yang diajar dengan model pembelajaran kontekstual secara umum lebih lengkap dibanding dengan siswa yang diajar dengan model pembelajaran kooperatif tipe STAD. Demikian juga halnya untuk butir soal nomor 3, siswa yang diajar dengan model pembelajaran kontekstual lebih lengkap dibanding dengan siswa yang diajar dengan model pembelajaran kooperati tipe STAD bahkan ada siswa yang tidak menjawab sama sekali.

Secara keseluruhan proses jawaban siswa yang mengikuti pembelajaran kontekstual lebih baik daripada proses jawaban siswa yang mengikuti pembelajaran kooperatif tipe STAD. Hal ini terlihat dari rata-rata keseluruhan proses jawaban siswa kelas eksperimen I 2,53 (Baik) dan rata-rata keseluruhan proses jawaban kelas eksperimen II 2,26 (Baik).

\section{KESIMPULAN}

Berdasarkan hasil analisis data penelitian dan temuan di lapangan yang

Asmy $\quad$ Susilawaty $\quad$ Saragih, Sahat Saragih $^{-}$Perbedaan Kemampuan Koneksi Matematik Siswa Melalui Pembelajaran Kontekstual dengan Kooperatif Tipe STAD di SMP Negeri 1 Silou Kahean. Jurnal Inspiratif, Vol. 4 No. 1 April 2018 
diuraikan pada bagian sebelumnya dapat disimpulkan bahwa:

1. Kemampuan koneksi matematik siswa yang diajar dengan model pembelajaran kontekstual lebih tinggi daripada siswa yang diajar dengan model pembelajaran kooperatif tipe STAD.

2. Proses jawaban siswa terkait kemampuan koneksi matematik siswa yang dengan model pembelajaran kontekstual lebih baik daripada siswa yang diajar dengan model pembelajaran kooperatif tipe STAD.

\section{REFERENSI}

Arikunto. (2009). Manajemen Penelitian. Jakarta: Rineka Cipta

Arikunto. (2012). Dasar-Dasar Evaluasi Pendidikan. Jakarta: PT Bumi Aksara

Abdurrahman, M., (2012), Anak berkesulitan belajar. Teori, diagnosis, dan remediasinya, Rineka Cipta, Jakarta.

Dahar, W. (2010). Teori-Teori Belajar \& Pembelajaran. Jakarta : Erlangga

Harahap, Tua Halomoan. (2013). Penerapan Contextual Teaching and Learning (CTL) Untuk Meningkatkan Kemampuan Koneksi dan Representase Matematika Siswa Kelas VII-2 SMP Nurhasanah Medan Tahun pelajaran 2012/2013. Tesis PPs Unimed: Tidak diterbitkan
Ngalimun. (2012). Strategi dan Model Pembelajaran. Banjarmasin: Aswaja Presindo

Rusman. (2012). Model-Model Pembelajaran. Jakarta: Rajawali Pers

Sudjana., (2009), Metode Statistika, Tarsito, Bandung.

Surya, E. 2009. "Pembelajaran Kooperatif dengan Pendekatan Berbasis Masalah dalam Pemecahan Masalah Matematika". Jurnal Pendidikan Matematika dan Sains, IV (1), 14-17.

Surya, E. Putri, F.A. and Mukhtar. (2017). Improving Mahematical Problem Solving Ability and SelfConfidence of High School Students Through Contextual Learning Model. Indonesian Mathematical Society Journal on Mathematics Education, 8(1), 8594.

Surya, E. and Syahputra, E. (2017). Improving High-Level Thinking Skills by Development of Learning PBL Approach on The Learning Mathematics for Senior High School Students. International Education Studies, 10(8), 12-20.

Surya, E., dkk.. (2013).. Improving of Junior High School Visual Thinking Representation Ability in Mathematical Problem Solving by CTL. IndoMS. J.M.E, Vol. 4 No. 1, pp. 113-126.

Trianto., (2009), Mendesain Model Pembelajaran Inovatif-Progresif, Kencana, Jakarta.

Asmy Susilawaty Saragih, Sahat Saragih $\quad$ Perbedaan Kemampuan Koneksi Matematik $\quad$ Siswa Melalui Pembelajaran Kontekstual dengan Kooperatif Tipe STAD di SMP Negeri 1 Silou Kahean. Jurnal Inspiratif, Vol. 4 No. 1 April 2018 